\title{
As Wives Too Beat Husbands: Another Look at the Socio-Legal Narratives of Domestic Violence
}

\author{
Babafemi Odunsi 1,2,3,4, Jade Mohammed ${ }^{5,6}$ \\ ${ }^{1}$ Faculty of Law, Obafemi Awolowo University, Ile-Ife, Nigeria \\ ${ }^{2}$ Faculty of Law, University of Toronto, Toronto, Canada \\ ${ }^{3}$ Faculty of Law, University of Pretoria, Pretoria, South Africa \\ ${ }^{4}$ Faculty of Law, University of the Free State, Bloemfontein, South Africa \\ ${ }^{5}$ Federal Polytechnic, Ede, Nigeria \\ ${ }^{6}$ Oyo State Judiciary, Ibadan, Nigeria \\ Email: babafemiodunsi@yahoo.com
}

How to cite this paper: Odunsi, B., \& Mohammed, J. (2021). As Wives Too Beat Husbands: Another Look at the Socio-Legal Narratives of Domestic Violence. Beijing Law Review, 12, 600-618.

https://doi.org/10.4236/blr.2021.122032

Received: December 7, 2020

Accepted: June 7, 2021

Published: June 10, 2021

Copyright (c) 2021 by author(s) and Scientific Research Publishing Inc. This work is licensed under the Creative Commons Attribution International License (CC BY 4.0).

http://creativecommons.org/licenses/by/4.0/

\begin{abstract}
In the conventional human rights, socio-legal and related discourse of domestic violence, focus has preponderantly been on men as the perpetrators, with wives or women as victims. This may be due to some factors. One is the entrenched empathy and solidarity with women as the "weaker sex" and usual victims. In such context, instances of women's acts of domestic violence tend to be perceived readily as "exceptional cases" where the women perpetrators "must have been pushed to the wall". Another possible factor is the mind-set to readily assume that wife-on-husband violence is "unlikely" or "improbable", based on gender differences in size and strength, coupled with the man being the domineering personality and "head" in conventional spousal heterosexual relationships. A third factor may be that women can readily and comfortably speak out about their experiences as victims of domestic violence with expectations of societal interventions. Conversely, due to ego or masculine dignity male victims of domestic violence may keep silent, thus leaving, mainly, the voices of women resonating as victims in the pertinent narratives. However, studies, on a notable scale, are showing the reality of males being victims of domestic violence perpetrated by females. This paper seeks to address the foregoing and related issues in the context of human rights and similar aspects. Among the issues to be engaged will the factors contributory to the muffling of the voices of male victims and need for a pragmatic balance in the protection of women and men against domestic violence.
\end{abstract}

\section{Keywords}

Human Rights, Women's Rights, Human Rights Law, Domestic Violence, 
Female-on-Male Violence, Wife-on-Husband, Male Victims

\section{Introduction}

Domestic violence has mostly been used for "husbands" in our society. This issue is a matter of concern both in urban and rural sector in the country, but we tend to forget that violence does not have a gender-(National Buzz, 2017).

Generally, research and discourse of domestic violence have centred on the perspective of wife abuse. Comparatively, the aspect of husband beating, or wives beating husbands, has not enjoyed similar focused attention (Steinmetz \& Lucca, 1988). As a commentary sums up the scenario, "[d]omestic violence has mostly been used for 'husbands' in our society... but we tend to forget that violence does not have a gender." (National Buzz, 2017). In the context of human rights jurisprudence and activism, this discriminatory mind-set may have been influenced by the long standing presentation or perception of human societies, especially sub-Saharan Africa, as "male dominated" or "patriarchal" with women subjugated to lower echelons, suffering myriads of discrimination and abuse.

As the Declaration on the Elimination of Violence against Women, 1993 noted, "violence against women is a manifestation of historically unequal power relations between men and women, which have led to domination over and discrimination against women by men and to the prevention of the full advancement of women, and that violence against women is one of the crucial social mechanisms by which women are forced into a subordinate position compared with men" (Declaration on the Elimination of Violence against Women, 1993). In that light, there have been robust drives at national and international human rights realms over the years to facilitate and sustain equality and fair deals for women through intellectual agitations, statutes, judicial interventions and treaties (Cook, 1994; United Nations, 1995; Odunsi, 2009; Odunsi, 2012).

This paper's authors, in some forms, have also offered academic and intellectual inputs into the discussions on women's liberation from patriarchal or any other form of oppression (Odunsi \& Olaleye, 2011; Mohammed, 2019). Quite true, women have experienced disadvantages in societal structures and interactions over the ages, and still do in different ways. Thus, the diverse and unceasing efforts to achieve emancipation and equality for the female gender are desirable, noble and commendable steps in the right direction. Hence, this paper is not primed to confront or distract from the important project of safeguarding women's rights and interests. Rather, the essence is to re-evoke the tenets of universality and general applicability of human rights with the attendant societal need and duty to safeguard the rights and legitimate interests of all. In this context, it becomes noteworthy that the essence of equality is not to rationalise or sanctify abusive behaviour from any gender, class or groups. 
It is in light of the foregoing that this paper examines the issue of husbandbeating in the scope of domestic violence. Among others, the societal attitudes to husband beating and elements that contribute to muffling the voices of male victims will be considered. Generally, the paper highlights the need to pragmatically appreciate and address the problem of women-on-men domestic violence.

\section{Setting the Tone of Discussion: D.0. Fagunwa's Tale of a King Serially Beaten by Wife}

Based on the perception of women as the "weaker sex", gender differences in size and strength, coupled with the man regarded as the domineering personality and "leader" in spousal relationships, incidents of wives beating husbands would appear improbable, unlikely or incredible. As a source succinctly captures the scenario, "When wives beat their husbands, no one wants to believe it" (Young, 2018). It would thus appear quite natural and apt that one prominent early literary account of a wife beating her husband in Nigeria happened to be in the realm of fiction. That is in the Yoruba language folkloric novel titled, Irinkerindo ninu Igbo Elegbeje first published in 1954 by D.O. Fagunwa.

D.O. Fagunwa was one of the foremost and pioneering literary work writers in Yoruba language (Adebowale, 2011). He was the author of a series of evergreen Yoruba language works, including Ogboju Ode ninu Igbo Irunmole, which had been translated into English language by the renowned Nobel Laureate in Literature, Wole Soyinka as Forest of a thousand Demons. a Hunter's Saga [D.O. Fagunwa, translated by Wole Soyinka] (Soyinka, 1982). The Yoruba is one of the predominant tribes or ethnic groups constituting the Federal Republic of Nigeria, found mainly in the south-western part of the country; in much smaller groups, they can also be found in parts of neighbouring West African countries of Republic of Benin and Togo (Awolalu \& Dopamu, 1979; Britannica, 1998; Falola \& Genova, 2006).

Fagunwa's tale of the "battered king", written in the Yoruba language but translated, as presented in this paper, by the authors was the story of Omugodimeji, King of the Edidare people, who periodically and serially got pummelled by one of his wives. The Edidare people, according to Fagunwa's account, were a remarkably simple-minded, gullible and uncoordinated people. From the lead author's childhood recollection, the word "Edidare" came to be a pejorative singsong description or label for a very foolish person. It typically went in the form: "Gongoshu Edidare, bi o ti gbon' to, be lo go' to" which can be simply translated as "Foolish Edidare, you are wise and foolish in equal measure."

The specific instance of domestic violence under consideration in Fagunwa's Igbo Elegbeje, stemmed from the king's "audacity" to protest his wife's nagging and demeaning abuses while the king was involuntarily and, apparently, grudgingly, undertaking a domestic chore of pounding yam meal in the kitchen under the truculent wife's command and monitoring. For daring to protest against his wife's belittling commentaries the king got a vicious slap from her, followed by a 
humiliating beating; at the end of the encounter, the wife had trounced and floored the king seven different times. For clarity, it is considered necessary to present, in a paraphrased format, translated accounts of the incident as given by the "brave hunters" who witnessed the fight; the "brave hunters" constituted the central characters in the Igbo Elegbeje narratives. Story of the Edidare people, including the domestic violence in question, was part of their experiences on their oddyssey.

After a while we no longer heard the sound of pounding, and shortly after there was a loud shout and commotion that the king was fighting and we started hearing rushing footsteps. We quickly ran to the scene and by the time of arrival there, the king's wife had floored the king, sitting on and pinning him down, while repeatedly raining vicious slaps on him. We separated them and rescued the king from his wife.

Soon as the king got up, he declared that he wanted another round of fightthat it was [our intervention in separating them] that prevented him from using some wrestling dexterity to turn table of the fight on his wife. The king broke free [from the peacemakers' hold] and charged at his wife-and in an instant, the wife had slammed him down again. Believing that he had something to prove, the king charged into third round of the fight; promptly the wife had floored and trashed the king again. In short, this woman floored the king seven times in our presence. After the king was lucky to be rescued after the seventh flooring and thrashing, he took to his heels with the wife in hot pursuit; she ran after him for a long while before abandoning the chase. (Fagunwa, 2005)

The manifestly sarcastic interrogation or enquiry into the circumstances of the fight at the place where the king sought refuge further illustrated the lack of empathy for the brutalised man. More particularly, the conversation reveals that the domestic terrorising of the king by the violence-inclined wife was not a one-off or isolated event; inferably, the king had been encountering series of such physical abuses from his wife. As the "brave hunters" accounts continue:

After the woman abandoned the chase, we went to the king at the place he stood and started to assist him in dusting off the dirt on his head-dirt that got tangled in his head when the woman was pummelling him on the floor... While this was going on, one of his chiefs observed, "Your majesty, she did not beat you today as much as that other day" the king replied "No, I am just understanding her fighting style; [you see, in this latest fight], I lifted her off ground to slam her down, but some debris/dirt hooked and affected my footing and enabled her to escape from my clutch". Another person further asked, "hope she did not kick you today" to which the king replied, "she did, but her kick did not hit me in a bad/dangerous place". Another person further asked, "Where is your crown?" the king answered, "My crown fell off into the mortar while the woman was battering me; I don't really 
know where the crown is now". (Fagunwa, 2005)

When asked the cause of the fight, the king explained, as stated earlier, that his protestation against the woman's nagging and abuses made her to slap him heavily, leading to the brawl. Amplifying, he stated,

[After a range of abusive words], I said she should stop abusing me; I did not say more than that, only to receive a violent slap to my ear. I crouched to clear off her legs and wrestle her to the ground; soon as I crouched, she gave me a violent kick that slammed my head against the "grinding stone". Don't think it was a trivial issue at all; the woman nearly broke my skull... but I am not surprised; that is how her mother broke the skull of her own father and caused her to be sentenced to prison. They are a family of headbreakers/skull crackers. (Fagunwa, 2005)

The commentary of a supposed "sympathiser" to the king was particularly poignant and pungent: "Your majesty, you need to brace-up [as a real man]! Your being beaten 'every time' by a woman is really shameful." (Fagunwa, 2005) The mocking and deprecating reactions of the witnesses or spectators to the king's ordeals are instructive in the situation of men abused by women in the contemporary and non-fictional settings. Such reactions and attitudes tend to keep voices of male victims muffled, with the attendant lack of proper attention to the issue. With likelihood of exposure to public mockery, ridicule and shame for being beaten by women, many men would rather opt to suffer their tragedies in silence and, as much as possible, put up a facade of unassailable masculinity.

\section{Wives Beating Husbands: Beyond Folklore}

In real life, there have been instances of wives and women perpetrating domestic violence against male spouses or partners. In this context, a report identified Egypt as the leading country where wives beat husbands, with UK and India taking second and third positions (National Buzz, 2017; CairoScene, 2016). From a statistical perspective, 28 per cent of Egyptian women beat their husbands, 23 per cent in the United States, 17 per cent in the U.K, and 11 per cent in India (CairoScene, 2016). In the US, the 2000 National Violence Against Women Survey by the National Institute of Justice and the 2010 National Intimate Partner and Sexual Violence Survey by the Center for Disease Control found that about $40 \%$ of those reporting serious assaults by current or former partners were men, with most of the attackers being women (Young, 2018). Furthermore,

[o]verall, studies find that female-on-male assaults account for $12 \%$ to $40 \%$ of injuries from domestic violence. Men also make up about $30 \%$ of intimate homicide victims, not counting confirmed cases of female self-defense. The 1998 killing of actor/comedian Phil Hartman by his wife, Brynn, who then committed suicide, is just one notable instance of a domestic murder in which the perpetrator with a history of violence was a woman. (Young, 2018) 
A report relating to the UK presents that "the number of women convicted of violence against a partner has increased six-fold over the past decade, from 806 in 2004/5 to 4866 in 2014/15" (Carroll, 2016). The report goes further to state that an organisation which runs a helpline for male victims of domestic violence "receives 1500 calls a year, some of them from concerned mothers or sisters of abused men" (Carroll, 2016).

Just as earlier narrated in D.O. Fagunwa's fictional story of the battered king, the UK Daily Mail presented real-life accounts of some men that encountered domestic violence from their wives (Carroll, 2016). For clarity, a verbatim extract of the first of the reported cases is considered apposite for illustration:

For nine years Paul [Chivers], a 47-year-old IT teacher, was scratched, punched and slapped by his 43 -year-old wife [Meena Chivers]. A special needs teacher at a secondary school, she showed compassion and patience with her young charges by day but, at home, her temper knew no bounds.

And Paul, out of shame and desperation to keep their family unit together for the sake of their young daughter, simply put up with it.

"To the outside world she presented a sweet, professional veneer, a smoke screen, and I went along with it because I worried about the consequences if I didn't," recalls Paul.

It was only after a shocking burst of temper, which saw Meena swing a hairdryer at her husband, splitting his head open and causing a wound that required eight stitches in hospital, that he finally accepted he needed help. Ironically, he was prompted by a phone call from their daughter's schoolthe 11-year-old had confided in her teachers about what she'd seen Mummy do to Daddy and the school got in touch.

"After that call I went to the police station to make a statement," he says.

In April last year, Meena was sentenced to 16 months in prison after being found guilty of unlawful wounding and common assault by a jury at Swindon Crown Court.

It can readily be imagined that, with the social outlook of Mrs. Chivers coupled with her vocation as a special needs teacher, a position that would require compassion and patience, she cannot be a "bad woman". Thus, the husband must have been provoking her indoor violent actions or reactions; put differently, the husband "asked for it". In another vein, it can be imagined that, possibly, Mr. Chivers suffered the domestic abuses because he was less physically strong than the wife thereby unable to defend himself or "physically put the wife in her rightful place". But this is not necessarily so, as the situations of two other men in the Daily Mail report would show.

Simon Smith stood at 6 feet 3 inches in height and a Royal Navy Leading Seaman. With his size and being a military man, he should have the masculinity, physical strength as well as tactical skill and training to defend himself, at least, against his wife. Yet, Smith suffered domestic physical and other abuses from the wife, whose nasty temper he knew of. For example, when he phoned his parents 
or siblings, the wife would demand the call be on speaker-phone so that she could hear both sides of the conversation. These came to head on the couple returning home after an outing where the woman had, perhaps, too much drinking. She started another quarrel in which she punched and threw a knife block at the husband. He went to their bedroom to pack a bag, planning to spend the night on his ship, HMS Lancaster, and give her time to calm down. Still, the woman crept upstairs after him with a kitchen knife, which she plunged twice into his back and once into his arm. He lost six pints of blood and underwent life-saving surgery in hospital. For this, the woman was ultimately jailed for nine years. The central reason why the man put up with the abuses despite his physical capabilities and military background, in his own words was, "I never hit her back. I would never hit a woman, no matter what" (Carroll, 2016).

Ian McNicholl, 53 was 5 feet 10 inches tall with a solid build in comparison with his partner, Michelle Williamson, 44, who stood at 5 feet linch, size 8 . Having brainwashed Mr. McNicholl into believing that she had brothers involved in organised crime who would kill him if he tried to leave her, she subjected the man to series of domestic abuse. "She fractured his skull, cheekbones and nose and cracked three of his ribs as well as pouring boiling water from a kettle into his lap, shoving a lighted cigarette up his nose, spraying bleach into his eyes and branding his arm with a steam iron. By May 2008, Ian... was virtually a prisoner in his own home, having lost contact with friends and family and neglected his business training NHS staff" (Carroll, 2016). The final attack in 2008 was one in which the woman attacked Mr. McNicholl with a metal bar and a hammer and for which she was sentenced to seven years for grievous bodily harm. The man's deliverance came through a neighbour who alerted police after seeing his facial injuries from the final attack. Actually, the man had lied to the police about the cause of the injuries on the instruction of the woman. It was the police officer's discovery that the man had old injuries that prompted further investigation leading to the trial and conviction. Generally, considering the couple's differences in size and physical build it would seem surprising that the smaller woman could wield such control.

The Smith and McNicholl scenarios offer some insight into why some men, even when physically capable of resistance or prevention, opt to tolerate domestic physical abuses from spouses. As in the case of Smith, they may not have violent disposition to physically engage women while some may labour under real or imaginary threats of greater harm, should they retaliate or act aggressively, as in the case of McNicholl. More so, as the perceived weaker sex, women are likely to enjoy psychological and sociological advantages of sympathy and credibility over men in such situations when disputes come for adjudication or resolution. As a commentator noted, "[a]bused men have faced widespread biases from police, judges and social workers, who tend to assume that the man in a violent relationship is the aggressor and to trivialize assaults by women." (Young, 2018). The case of allegation and counter-allegation of domestic abuses involving Ame- 
rican Presidential speech-writer, David Sorensen offers an illustration; Sorensen had to resign his position in President Trump's government following his exwife's public accusations of domestic abuse. Despite efforts to establish his being a victim too of the ex-wife's abuses, he did not seem to enjoy as much empathy or credibility as the wife (Young, 2018).

\section{Wife-on-Husband Violence in "Male-Dominant" Sub-Saharan Africa: Kenya and Nigeria in Perspective}

Generally, wife-on-husband violence is not confined to any particular national or continental boundary. It may be imagined that the occurrences in the locations, such as US and UK, are due to the relative sociological tolerance or empathy for women complemented by "women friendly" legal structures. However, that male dominant societies, such as Egypt and India, have been listed among the three leading countries with highest incidents of wife-on-husband domestic violence explains that that the problem transcends socio-legal outlook or legal structures.

Perhaps, one may imagine further that such phenomenon could not occur in "Black Africa" or sub-Saharan Africa. The reasoning would be that this is a region where women have historically operated under male dominance, with men indoctrinated to be strong and unsparing in the control of their householdswhich can consist of several wives and children in polygamous settings (Odunsi, 2009). In such setting where women are put in their "right positions", women inflicting violence on men would seem unimaginable.

However, there have been reports of the occurrences of female-on-male domestic violence in sub-Saharan Africa as well. One prominent study in this regard is Julius Gathogo's "Men battering as the new form of domestic violence? A pastoral care perspective from the Kenyan context" (Gathogo, 2015). This was a research on domestic violence by women against men in different parts of Kenya. The study, presumably, was spurred by the widely publicised news of two men viciously assaulted by their wives at home, one with a machete and the other with hot water. In perspective, the author noted, "[a]s it turned out, the above attacks opened a can of worms, as more information regarding battering of men by their spouses, outside the Central region of Kenya, began to show in the social media" (Gathogo, 2015).

Such bizarre cases of men being battered by their wives in Kenya have recently caught the national psyche as it goes against what has been the "norm," that is, aggression against women. The magnitude of the injuries also raised eyebrows, and presented the need to find lasting solutions so as to end violence in the family domain. Compounding the problem is that on 09 February 2012, the respected Kenyan newspaper, the Daily Nation, carried a well-researched article, "Central Kenya top husband-beaters"-in which it highlighted the "state of the Nation" (Gathogo, 2015). 
Nigeria too has not been immune from occurrences of wife-on-husband violence, despite the historical and sociological perception of the country as a "male-dominated" one with women largely subjugated (Odunsi, 2009). As some cases discussed below will show, some of the Nigerian wives-on-husbands violence result in fatalities, taking the matter notches over and above the reported incidents in Kenya where the husbands merely suffered injuries. Two widely reported cases are pertinent. In the first incident, the wife in a rage of violence attacked her husband and stabbed him to death; thereafter she proceeded to mutilate his body including cutting off his genitals (Punch Newspaper, 2018). This attack on the man, from indications, was not unleashed while he was unconscious or unprepared; according to a witness to the incident the deceased before he was killed had called his mother to complain that his wife was hitting him and had a knife (Punch Newspaper, 2018; Dania, 2019).

The second widely reported case of fatal wife-on-husband domestic violence also involved a female lawyer-in Ibadan, Nigeria (The News, 2016). The case illustrated the possibility and capacity of some women to initiate, continue and sustain domestic violence to gruesome ends. Following an argument, the wife had stabbed the husband with a knife for which he was taken to hospital for treatment. On return, the man was advised to take refuge in another place for the night away from the wife. However, trusting that the wife had calmed down and would no longer engage in violence against him, the man insisted on going back to his wife for the night. Subsequently, the wife stabbed him to death.

Apart from the above mentioned two, there have been several other cases of wives-on-husbands violence in Nigeria over the years (Oloyede, 2020). Thus, while the ubiquity of social media may have amplified reports of such incidents in recent times, they have been occurring in Nigeria over the years. The lead author recalls a pathetic one that happened in his neighbourhood, around 1989 or 1990. The husband with whom the wife had twin children lost his job and consequently turned his private car to taxi cab. There had been quarrels and arguments between the couple at different times. One night the man lay relaxing on the bed after returning from his daily taxi cab runs. Suddenly, without any hint, the wife came from outside and poured heated and very hot vegetable oil all over the man where he laid. The lead author saw co-tenants rushing the man to a nearby hospital; unfortunately, the man died on the second or third day from the burn injuries. Also while with the Lagos Ministry of Justice between 1989 and 1990 the lead author knew of the case of a woman being prosecuted for slaughtering her husband with whom she had four children or so. As background to the case, the couple had a fallout in their marriage; following a later reconciliation they went to a hotel for a sort of retreat. In the course of the rendezvous, the woman, ostensibly, by some means tranquilised the man. She then proceeded to slit the throat of the sedated and prostrate man with a knife she had brought along.

When wife-on-husband violence results in death, there is the propensity to at- 
tract media attention due to the criminal colouration among other factors. However, it is possible that many non-fatal cases may go without receiving widespread attention. Moreover, for different reasons, such cases may be unreported or can be resolved amicably between the couples.

It is arguable that the sporadic incidents of fatal domestic violence involving women as reported in Nigeria may have been due to the women involved being "pushed to the wall". Also, with husbands-on-wives violence still dominating the discourse of domestic violence (Oloyede, 2020), the occasional occurrences of wives-against-husbands violence may appear as "exceptions to the rules". Thus, generally, it may be reasoned that wives-against-husbands violence, fatal or non-fatal, is not endemic and hence not a "so serious" issue in the Nigerian context. However, there are indications that the issue may be more serious than it appears, going by some developments. Quite recently, the lead author, through a social media platform, came across a flyer or poster by which, a civil society group, Movement Against Domestic Abuse by Men (MADAM), offers help-line for male victims of domestic violence (Folorunsho-Francis, 2020). Under a conspicuous heading of "Domestic Violence" was written a clarion-call, "Save a Man today". Then, via a brief write-up, the organisation urges male victims of domestic violence to contact its Men Help Centre, as well as anyone who has information about a male suffering domestic violence. Physical address, phone contact and email address of the organisation were stated on the poster or flyer.

The emergence and activities of organisations of this nature in Nigeria give some insight into the incident of wife-against-husband violence. Basically, it confirms that the incident is a reality in Nigeria, despite the facade of the country being a "male dominated society". Secondly, that the incident, the occurrences of which have been shrouded in concealment, has got to a level of serious concern. A comment of the Executive Director of the organisation is pertinent in this context:

A man just complained to us today that his wife battered him. The assault has made him run away from home for three days. Now he cannot go back for fear she could attack him again. Today, many men hang around beer parlours till late in the night because they are scared of returning home to meet an abusive spouse. When they eventually make it home late, they are up again by 4.00 am to 5.00 am preparing to dash out. They have lost the ability to manage a violent spouse (Folorunsho-Francis, 2020).

\section{Unheard Voices of Male Victims: Contributory Circumstances and Factors}

Despite the reality and extent of wife-on-husband violence in different parts of the world, it appears that the phenomenon is relatively underreported and underappreciated (Gathogo, 2015; Folorunsho-Francis, 2020). Reasons for low reporting in one respect can be attributed to the fact that male victims, unlike female victims, tend to not readily speak out about the experiences. This scenario 
can be attributed to cultural, religious, economic, sociological as well as psychological factors.

The factors are interwoven in different respects, as the interplay of cultural and psychological factors would readily illustrate. In the sub-Saharan African socio-cultural settings, men are perceived as the stronger sex and women stereotyped as the weaker sex. Thus, a situation of a man being beaten by his wife is inherently incomprehensible. Such would readily expose the man to mockery and loss of esteem for "not being a real man" (Gathogo, 2015). Where a man is experiencing domestic violence from his wife, he may not want his ordeal to be exposed to others and may rather opt to silently bear the pain. The thinking would be that raising his voice to cry for help may turn his situation to object of damaging gossips and ridicule. With such mentality pervading, it becomes difficult for victims to go public on their ordeals or make reports to official authorities (Gathogo, 2015).

In some cases, victims overcome or defy the socio-cultural and psychological odds to approach official authorities. Unfortunately, victims in such situations tend to encounter insensitive reactions even from official quarters (Young, 2018). As one source presents the typical scenario,

[o]ver time, we have discovered that when you refer these men, there is a preconceived judgement in some of these referral centres including the Office of the Public Defender.

From the moment the victims start narrating that they were beaten up by their spouse, they tend to get discouraged by the attitude of some officials. Some men are further subjected to mockery and probing questions on why they didn't submit willingly to avoid being battered (Folorunsho-Francis, 2020).

Naturally, unsympathetic attitudes of officials tend to dampen the morale of aggrieved victims as well as propel others to forlornly keep their experiences private rather than risking getting more salts rubbed on their wounds with another level of mockery from officials who ought to alleviate their burdens. Embedded in the official attitudes is another inhibiting factor that tends to keep male victims silent-the fear of not being believed if they publicise their experience of domestic violence (Young, 2018). The unsympathetic official attitudes, perhaps, indicates an official mind-set that that women-on-men domestic violence is not an issue of serious concern; by extension this may have accounted for non-provision of social amenities like refuge homes or shelters to meet the temporary needs of male victims for whom their homes have become hostile territories (Carroll, 2016; Young, 2018).

In some contexts, economic reasons may account for the silence of male victims of domestic violence. Due to circumstances, some men may be dependent on wives for their sustenance and that of the family as whole. Where such men suffer abuses, the fear of losing economic lifelines through divorce or abandonment may compel such men to suffer in silence (Gathogo, 2015). Along same 
line, the possibility of other forms of suffering or threat of same, or other considerations, may compel male victims to remain silent or accommodate the abuses. For example, the an abusive wife threatened the abused husband that she had brothers involved in organised crime...who would kill him if he tried to leave her. With that hanging threat, she subjected the man to fifteen months of abuse. "She fractured his skull, cheekbones and nose and cracked three of his ribs as well as pouring boiling water from a kettle into his lap, shoving a lighted cigarette up his nose, spraying bleach into his eyes and branding his arm with a steam iron" (Carroll, 2016).

In some situations religion too may keep the victims from speaking out. Religious couples may interpret abuses as "work and attack of the devil" to test their faith or put asunder their marriage. Rather than taking steps to address the problem, the victims may opt to resist the devil and bear the suffering with prayers and faith trusting that the siege will lift at some time. Reference to precedents of revered religious figures who had victoriously fought battles of faith in the past can be good consolation or pointer to such people. In some cases, where victims report to their religious leaders they may be counselled to "seek the face of God" rather than washing their dirty linen in public (Gathogo, 2015).

\section{Domestic Violence: Journey to Freedom and Protection of Women's Rights in perspective}

To recap, the perception and narrative on domestic violence is that men are the culprits and women are the victims. Consequently, in one respect, it is unexpected that women would have the physical or other capacity to inflict violence on men, based on typical gender differences in size and strength. Women-on-men violence is thus assumed to be "improbable" or, at worst, harmless, making it difficult to comprehend or acknowledge occurrences of such acts of violence. Even, with reports of women-on-men violence, the perception remains that such attacks would have justification in that the violence-dispensing women must have been pushed to the wall. In essence, in the domestic violence narrative, men encounter prejudices in different ramifications.

The centre-point of the mind-set and narrative is that women constitute the "weaker sex" who need liberation and protection from dominance of men in historically patriarchal societal settings. It is trite that over the ages, in comparison with men, women across the world have suffered disadvantages and deprivations in different dimensions (Declaration on the Elimination of Violence against Women, 1993). In that light, pursuit of the emancipation of women and safeguarding of their human rights is much desirable and noble.

Generally, there have some notable special developments in the area of safeguarding the interests and rights of women. One was the adoption of the Convention on the Elimination of All Forms of Discrimination against Women (CEDAW) adopted by the United Nations General Assembly on 18 December 1979, entering into force on 3 December 1981. Though the CEDAW does not 
explicitly mention violence against women and girls, General Recommendations 12,19 , and 35 clarify that the Convention includes violence against women and makes detailed recommendations to States (CEDAW, 1979). Subsequently, the 1993 World Conference on Human Rights recognized violence against women as a human rights violation and called for the appointment of a Special Rapporteur on violence against women in the Vienna Declaration and Programme of Action (World Conference on Human Rights, 1993; UNWOMEN.ORG, 2020).

In more expressly engaging the issue of violence against women, the United Nations adopted the Declaration on the Elimination of Violence against Women. The 1993 Declaration on the Elimination of Violence against Women was the first international instrument explicitly addressing violence against women, providing a framework for national and international action (UNWOMEN.ORG, 2020). In 1994, the International Conference on Population and Development (ICPD) was held in Cairo Egypt (United Nations, 1994). Apparently, in presenting the multidimensional impact of violence against women and need to control it, the Conference drew links between violence against women and reproductive health and rights (UNWOMEN.ORG, 2020). These earlier foundations set the tone for the different declarations and injunctions on the rights of women and issues affecting women adopted at the widely publicised and well attended Fourth United Nations International Conference on Women in 1995, held in Beijing, China (Beijing Conference). Among others, in aspects touching on violence against women, the Beijing Platform for Action identifies specific actions which governments should take to prevent and respond to violence against women and girls. Ending violence is one of 12 areas for priority action (UNWOMEN.ORG, 2020).

Beyond Beijing and the other earlier noted instruments and actions, there have been other international drives on the protection of women against violence. At regional level, for example, in 2011 the Council of Europe adopted the Council of Europe Convention on preventing and combating violence against women and domestic violence (UNWOMEN.ORG, 2020). This is a legally binding regional instrument on violence against women and girls. Prior to that, at the African regional level the African Regional Strategy on Reproductive Health was devised in September 1997 (African Regional Strategy on Reproductive Health, 1997). Though the main focus was reproductive health, its scope and aspiration included the elimination of harmful practices and sexual violence. In a related vein, building on the generally applicable African [Banjul] Charter on Human and Peoples' Rights, the Protocol to the African Charter on the Rights of Women was specifically fashioned out and tailored to further safeguard the rights and interests of women. Among others, the Protocol calls for the adoption and implementation of measures to: 1) protect women from all forms of violence whether sexual or verbal, and whether in public or private, 2) generally to prevent, punish and eradicate violence against women 3 ) eradicate elements and stereotypes in traditional and cultural beliefs, which legitimize and exacerbate violence against 
women (Njoroge, 2005).

By and large, international efforts in protecting women against violence have been a continuing process. As an illustration of the continuity, in 2020, at the 64th session of the Commission on the Status of Women, leaders pledged to ramp up efforts to fully implement the Beijing Declaration and Platform for Action, including ending all forms of violence and harmful practices against women and girls, (UNWOMEN.ORG, 2020). Similarly, in ensuring that the project is not far from global attention, the United Nations General Assembly by resolution 54/134 of 17 December 1999 adopted and designated 25 November as the International Day for the Elimination of Violence against Women (World Health Organisation, 1999). International days are occasions to educate the public on issues of concern, to mobilize political will and resources to address global problems, and to celebrate and reinforce achievements of humanity; the UN has embraced them as a powerful advocacy tool (United Nations, 2020). Typically, celebration of International days entail invitations to governments, international organizations and NGOs to organize activities designed to raise public awareness of the pertinent problem on that day (World Health Organisation, 1999). The effect of the designation of the International Day for the Elimination of Violence against Women is that at least for several days every year the issue of violence against women will be receiving robust and multidimensional attention at different fora across the world. The theme for the 2020 International Day for the Elimination of Violence against Women is "Orange the World: Fund, Respond, Prevent, Collect." Like in previous years, the year's International Day will mark the launch of 16 days of activism that will conclude on 10 December 2020, which is International Human Rights Day (United Nations, 2020).

At domestic level too, there have been promulgations of diverse statutes specifically designed to address violence or some other issues affecting women. With Nigeria as illustration, some examples of such statutes are:

1) Violence Against Persons Prohibition Act 2015

2) Domestic Violence Against Women (Prohibition) Law No.10 of 2004 Cross Rivers

3) Domestic Violence and Other Related Matters Law of (2006) Jigawa State.

4) Infringement of a Widow's Fundamental Rights Law No. 3 of (2005) Enugu State

5) Inhuman Treatment of Widows (Prohibition) Law 2004 of Edo state

6) Malpractices against Widows and Widowers (Prohibition) Law 2005 Enugu.

7) Protection against Domestic Violence Law Lagos No. 15A 199 (2007).

While some of the noted statutes may not bear citations that specifically denote specific application to women, it can be readily inferred or understood that women constitute the main or intended focus of protection. The Protection against Domestic Violence Law Lagos No. 15A 199 (2007) illustrates this point (Ojigho, 2009). 


\section{Balancing the Narratives: Allegory of "Minority Protection"}

From preceding discussions, it is manifest that from the perspectives of society and law, women are primarily deemed the victims of domestic violence who deserve protection from men as perpetrators of the violence. Consequently, in terms of societal attitudes, and discourse in academic and related areas, femaleon-male gender violence has been largely avoided or denied serious attention (Steinmetz \& Lucca, 1988). As shown in the preceding section, International and National laws have equally manifested great bias in the attention given to protecting women against violence in comparison with the male gender. This should not be surprising with the position of the United Nations that violence against women flows from unequal power relations between men and women, which have led to domination over and discrimination against women by men and hindering women from appropriate advancement (Ojigho, 2009).

With men-on-women domestic violence predominating in the gender violence narratives, and likely to continue dominating, the voices and fate of male victims of domestic violence stand muffled and shrouded in the slanted terrain of discourse. Perceptibly, men are the strong ones who need no socio-legal protection as they can take care of themselves, or are the people from whom women need to be protected. Quite true, statistics and reports reflect that women are more at the receiving end of domestic violence, or that domestic violence affects women more than men (Oloyede 2020; World Health Organisation, 1999; United Nations, 2020). However, the reality is that, across the world, a proportion of women perpetrate domestic violence on men and there are men who suffer spousal domestic violence, even if not many. Hence, the situation of the men should not remain trivialised, unacknowledged or obfuscated in the socio-legal equation under whatever presumption that has been eroded by harsh facts of some women's capacity and propensity for gory violence.

The global community, over the years, has engaged the protection of the interests and rights of minorities or marginalised people (United Nations, 1998). Thus, if we go by the logic and comparative statistics that just a minority or fractions of men suffer spousal domestic violence, then, the situation of these men can be considered in the framework of "minority protection". Their situation would thus deserve the special attention and protection as "minority group" among the general body of women who need help because of their special circumstances as gender-based violence victims. Along that line, they deserve attention along the level available for female victims of domestic violence under national and international laws.

It is trite that there are salient provisions under generally applicable national laws to address gender violence; and women who inflicted violence on spouses or partners have been sanctioned under such laws (Carroll, 2016). Perhaps, it can be reasoned that these laws should be sufficient modes of redress for the "occasional" and "relatively few" instances of women-on-men violence. Put dif- 
ferently, that the situation of male victims of spousal violence is not serious enough to deserve "special needs" interventions and dedications as have been given to womenfolk who are the major and regular victims of domestic violence.

Whatever may be the practical or academic platform for the above reasoning, in effect, it simply begs the issue. The same legal regimes for sanctioning and which seemingly suffice to protect men as victims are also available to protect women as victims. Yet, situation of women has not been left simply to such laws, as the special and supplementary attention in different forms given at international and national levels readily show. Above all, the ultimate goal of the crusade on violence against women is to "eliminate violence against women" (United Nations, 2020). In perspective, the global vision should be to eliminate violence against all without any gender delineation or discrimination. In that regard, however small in volume or infrequent female-on-male violence may be, the goal as in the case of females, should be eradication and not mere periodic sanctioning of female perpetrators of domestic violence. This dictates that similar attitudes, measures and approaches should be committed to both. That is the fundamental essence of equality and non-discrimination.

\section{Conclusion}

The vulnerability of women or the female gender as a whole dictates that appropriate safeguards should be in place to protect their rights and interests. The historical march of women from patriarchal domination and subordination to relative liberation has been long, cutting across different challenging terrains. All the gains made so far on women's march to emancipation and equality stand to be imperilled by domestic violence if not properly tackled. In this light all the efforts and measures deployed at national and international levels to confront violence against women cannot reasonably be faulted. The authors of this paper, through academic and other contributions, (Odunsi \& Olaleye, 2011; Mohammed, 2019) have participated in the global clamour for women's liberty and gender equality and remain in support of the global move against any form of violence against women. They thus endorse all the measures and approaches adopted at various levels to combat the menace.

Without prejudice to the foregoing, it is also important to collectively and robustly address and engage violence against any gender, group or individual under any guise whatsoever. It is in that context that this paper has canvassed the pertinent need to realistically and effectively confront the trending incidents of women-on-men violence without any discrimination. The starting point is to appreciate the unquestionable capabilities of women to dispense violence on same level as men, or worse-as some instances discussed in this paper show. In the words of Cathy Young, "Equality should include recognising women's potential for abusive behaviour" (Young, 2018). This dovetails into a sober and holistic engagement of women-on-men violence at national and international levels. Among others, there should be appropriate empathy for male victims, eschewing 
postures or actions that will keep their voices muffled or suppressed.

In the prevailing state of the overwhelming dominance of male-on-female aspect in the gender violence narratives with the attendant social and legal solidarity disproportionately tilted towards women, discussion of women-on-men domestic violence tends to be emotive and a difficult project to pursue.

Partner violence by women is one of the most contentious subjects in social science... Discussions of female-on-male abuse have been met with extreme hostility from feminist academics, activists and commentators. Scholars studying the subject have been attacked as apologists for misogyny. Battered women's advocates tend to explain away female violence as almost entirely defensive, despite evidence to the contrary. One reason for this attitude is solidarity with women as victims; another is the dogmatic view that battering is an expression of patriarchal power (Young, 2018).

All the same, the reality of women-on-men violence dictates that proactive and realistic attention is given to the phenomenon. What is bad for the geese should be bad for the gander and vice versa. The scenario of creating special sociological and legal attention for female victims of domestic violence, without similar attention to male victims would appear to be tacit discrimination. Domestic violence by any gender, or to any gender, is not an issue that should be trivialised or overlooked on the basis of relative magnitude of occurrences, presumption of masculinity or such other factors.

\section{Conflicts of Interest}

The authors declare no conflicts of interest regarding the publication of this paper.

\section{References}

(1979). Convention on the Elimination of all forms of Discrimination against Women $(C E D A W)$. Adopted by the United Nations General Assembly on 18 December 1979, Entered into Force on 3 December 1981.

(1993). Declaration on the Elimination of Violence against Women. Proclaimed by General Assembly Resolution 48/104 of 20 December 1993. https://www.ohchr.org/EN/ProfessionalInterest/Pages/ViolenceAgainstWomen.aspx

(1993). World Conference on Human Rights, Vienna. https://www.ohchr.org/EN/ABOUTUS/Pages/ViennaWC.aspx

(2003). Protocol to the African Charter on Human and Peoples' Rights on the Rights of Women in Africa (Maputo Protocol). The 2nd Ordinary Session of the Assembly of the African Union, Maputo, on 11 July 2003; Entered into Force 25 November 2005. http://www.achpr.org/english/ info/women en.html

Adebowale, B. (2011). "Late D.O. Fagunwa, Life and Works" Lecture Delivered on the Occasion of Fagunwa Night, Organized by Society of Young Nigerian Writers on Saturday 25th February, 2011 at U.I. Amphi-Theatre, Ibadan.

African [Banjul] Charter on Human and Peoples' Rights (1981). OAU Doc. CAB/Leg/ 67/3 Rev. 5, 21 ILM 58 (1982), Entered into Force 21 Oct. 1986 (Domesticated in Nige- 
ria as African Charter on Human and People's Rights Act Cap. A9 Laws of the Federation of Nigeria 2004).

Awolalu, J. O., \& Dopamu, P. A. (1979). West African Traditional Religion. Ibadan: Onibonoje Press \& Book Industries (Nig.) Limited.

Britannica (1998). Yoruba People. https://www.britannica.com/topic/Yoruba

CairoScene (2016). Egyptian Wives Ranked \#1 Internationally for Beating Their Husbands [Official Statistics Show That Almost 30 Percent of Women Beat Their Husbands]. https://thecairoscene.me/Buzz/Egyptian-Wives-Ranked-1-Internationally-For-BeatingTheir-Husbands

Carroll, H. (2016). Why Are So Many Middle Class Wives Beating Up Their Husbands? FEMAIL Explores Why Women Are Lashing Out at Their Partners and the Horrifying Consequences. Daily Mail.

https://www.dailymail.co.uk/femail/article-3506929/Why-middle-class-wives-beatinghusbands-FEMAIL-explores-women-lashing-partners-horrifying-consequences.html

Cook, R. J. (1994). Human Rights of Women, National and International Perspectives. Philadelphia, PA: University of Pennsylvania Press.

https://doi.org/10.9783/9780812201666

Dania, O. (2019). Udeme, Female Lawyer, Confessed to Killing Husband, Police Tell Court. Vanguard.

https://www.vanguardngr.com/2019/01/udeme-female-lawyer-confessed-to-killing-hus band-police-tell-court

Declaration on the Elimination of Violence against Women (1993). Proclaimed by General Assembly Resolution 48/104 of 20 December 1993.

https://www.ohchr.org/EN/ProfessionalInterest/Pages/ViolenceAgainstWomen.aspx

Fagunwa, D. O. (2005). Irinkerindo ninu Igbo Elegbeje. Lagos: Nelson Publishers Ltd.

Falola, T., \& Genova, A. (2006). Yorúbá Identity and Power Politics (Vol. 22). Rochester, New York: Boydell \& Brewer. http://www.jstor.org/stable/10.7722/j.ctt81p3p

Folorunsho-Francis, A. (2020). Men Suffering Domestic Violence in Silence at Risk of Depression-Experts. Punch.

https://healthwise.punchng.com/men-suffering-domestic-violence-in-silence-at-risk-of -depression-experts

Gathogo, J. (2015). Men Battering as the New Form of Domestic Violence? A Pastoral Care Perspective from the Kenyan Context. Theological Studies, 71, a2795. https://doi.org/10.4102/hts.v71i3.2795

Mohammed, M. J. O. (2019). Safeguarding the Socio-Economic Rights of Women in Nigeria in the Framework of International Human Rights Law. Thesis, Ile-Ife: Obafemi Awolowo University.

National Buzz (2017). Indian Wives Have Been Ranked Third in the World in Beating Husbands: Survey.

http://nationalbuzz.in/indian-wives-have-been-ranked-third-in-the-world-in-beatinghusbands-survey

Njoroge, A. K. (2005). The Protocol on the Rights of Women in Africa to the African Charter on Human and Peoples; Rights (The Maputo Protocol). Thematic Session II during the Sub-Regional Conference on Female Genital Mutilation (FGM), Djibouti, 2-3 February 2005. http://www.npwj.org/GHR/Other-Papers-presented-Conference.html

Odunsi, B. (2009). Changing Attitudes to Polygamy and Women's Struggle for Equality in Nigeria. Akungba Law Journal, 1, 375-397. 
Odunsi, B. (2012). Some Perspectives on the Reproductive Rights of HIV Positive Women Not to Bear Children. East African Journal of Peace and Human Rights, 13, 271-299.

Odunsi, B., \& Olaleye, F. (2011). Courts and the Need for Dynamism in the Promotion of Reproductive Health Rights: A Nigerian Perspective. East African Journal of Peace \& Human Rights, 17, 160-171.

Ojigho, O. (2009). Prohibiting Domestic Violence through Legislation in Nigeria. Agenda, 26, 86-93.

https://www.researchgate.net/publication/233304725 Prohibiting domestic violence t hrough legislation in Nigeria

Oloyede, C. A. (2020). Nigeria: How Maryam Sanda Bagged Death Sentence for Husband's Murder. Daily Trust. https://allafrica.com/stories/202001280574.html

Punch Newspaper (2018). How Female Lawyer Killed, Mutilated Husband's Body-Witnesses. Punch.

https://punchng.com/how-female-lawyer-killed-mutilated-husbands-body-witnesses

Soyinka, W. (1982). Forest of a Thousand Demons: A Hunter's Saga [D.O. Fagunwa, Translated by Wole Soyinka]. San Francisco, CA: City Lights Books.

Steinmetz, S. K., \& Lucca, J. S. (1988). Husband Battering. In V. B. Van Hasselt, R. L. Morrison, A. S. Bellack, \& M. Hersen (Eds.), Handbook of Family Violence (pp. 233 246). Boston, MA: Springer. https://doi.org/10.1007/978-1-4757-5360-8 10

The News (2016). Inside Story: How Yewande, Ibadan Lawyer Killed Her Husband. The News.

https://www.thenewsnigeria.com.ng/2016/02/07/inside-story-how-yewande-ibadan-la wyer-killed-her-husband

United Nations (1994). Report of the International Conference on Population and Development Cairo, Egypt, 5-13 September 1994. United Nations Doc. N.Y. A/Conf. 171/13 Rev.1, U.N. Sales No. 95. XIII.I8 1994.

United Nations (1995). Report of the Fourth World Conference on Women [the Beijing Declaration and Platform for Action]. United Nations Doc., New York, N.Y, A/Conf. 177/20, 1995.

United Nations (1998). Fact Sheet No.18 (Rev.1), Minority Rights. https://www.ohchr.org/Documents/Publications/FactSheet18rev.1en.pdf

United Nations (2020). International Day for the Elimination of Violence against Women 25 November.

https://www.un.org/en/observances/ending-violence-against-women-day

UNWOMEN.ORG (2020). Global Norms and Standards: Ending Violence against Women. https://www.unwomen.org/en/what-we-do/ending-violence-against-women/global-nor ms-and-standards

World Health Organisation (WHO) (1999). International Day for the Elimination of Violence against Women.

https://www.who.int/life-course/news/events/intl-day-elimination-of-violence-againstwomen/en

Young, C. (2018). Op-Ed: When Wives Beat Their Husbands, No One Wants to Believe It. Los Angeles Times.

https://www.latimes.com/opinion/op-ed/la-oe-young-sorenson-male-domestic-abuse20180222-story.html 